\title{
Copper in Galician ria sediments: natural levels and harbour contamination
}

\author{
ANA GARCÍA, PATRICIA BERNÁRDEZ and RICARDO PREGO \\ Marine Research Institute, CSIC, Eduardo Cabello 6, 36208 Vigo, Spain. E-mail: prego@iim.csic.es
}

\begin{abstract}
SUMMARY: Copper distribution, natural background and contamination levels in sediments of the Galician rias were assessed from 389 surface sediment samples and five sediment cores. The natural reference concentration of copper can be estimated using the $\mathrm{Cu}-\mathrm{Fe}$ relationship obtained from preindustrial sediments of rias: $\left[\mathrm{Cu}\left(\mathrm{mg} \mathrm{kg}^{-1}\right)\right] /\left[\mathrm{Fe}\left(\mathrm{g} \mathrm{kg}^{-1}\right)\right]=0.55$. Severe copper contamination was mainly observed in the harbour, fishing ports and shipyards near shore areas of the Galician coast. Therefore, the rias of Ferrol and Vigo were the most environmentally disturbed, while the northern Galician rias were the least disturbed. The Galician case can be seen as the type of copper contamination due to maritime activities observed in other world harbours.
\end{abstract}

Keywords: metal, sediment, background concentrations, harbour, ria, NW Iberian Peninsula.

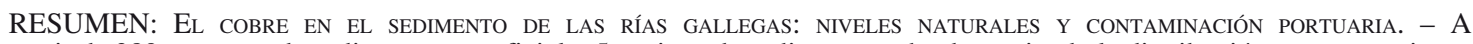
partir de 389 muestras de sedimento superficial y 5 testigos de sedimento se ha determinado la distribución, concentraciones naturales y niveles de contaminación por cobre en los sedimentos de las rías gallegas. En base a sedimentos preindustriales se ha obtenido una correlación entre hierro y cobre aplicable a las rías: $\left[\mathrm{Cu}\left(\mathrm{mg} \mathrm{kg}^{-1}\right)\right] /\left[\mathrm{Fe}\left(\mathrm{g} \mathrm{kg}^{-1}\right)\right]=0.55$. Al calcular con esta ecuación los factores de enriquecimiento por cobre del sedimento superficial se ha detectado una fuerte contaminación en las zonas portuarias y de astilleros en la costa gallega. Bajo este aspecto son las rías de Ferrol y Vigo las más alteradas mientras que lo contrario ocurre con las rías del norte de Galicia. Este tipo de contaminación por cobre en el noroeste de la península Ibérica se suma a algunos casos derivados del tráfico y construcción de buques observados en otras áreas costeras del planeta.
\end{abstract}

Keywords: metal, sedimento, concentraciones de fondo, puerto, ría, España.

\section{INTRODUCTION}

Copper is a ubiquitous element in the earth's crust, from which it is moved by weathering to coastal sediments. Copper is accumulated in sediments together with its autochthonous sea source due to plankton sedimentation. Although copper is an essential micronutrient for living organisms (Scheinberg 1991), it can become poisonous to marine life when its concentration increases in the surroundings (Long et al. 1995). For this reason, copper has been employed as an algaecide and molluscicide in water (Schiff et al. 2004) and it is a component of antifouling paint for ship bottoms. The typical source of copper in marine environment contamination is industrial discharges and atmospheric deposition. Fungicides, wood preservatives and boat antifouling paints can also contribute to high levels of copper in the aquatic environment. Most imported and exported goods travel by sea, resulting in a continuous increase in shipyard activities and maritime traffic. Therefore, the copper input in the coastal environment rises every day and the areas around ports decay. Moreover, the ban on using TBT on smaller vessels has resulted in the shift back to the use of copper as the main biocide. Copper present in the water and sediments can be accumulated by benthic animals, causing, for example, reduced respiration rates and impaired growth in mussels, clams and other shellfish (Kennish 1992, Sobral and Widdows 1997).

The influx of copper that leaches from these paints is the main copper load to the Bay of San Diego (Seligman et al. 2001, Valkirs et al. 2003), and is also the rea- 
son for the increase in metal contamination observed in the Pacific harbour sediments (Wolanski 2006). This type of contamination in the sedimentary reservoir has been studied in the main Atlantic harbours of the USA (New York: Feng et al. 1998; Baltimore: Mason et al. 2004) and France (Fichet et al. 1999). Nevertheless, it has been poorly investigated in the Iberian Peninsula and particularly in the Galician rias, where lead and zinc contamination in sediments of the four main harbour areas of Galicia (Ferrol, Coruña, Marín and Vigo) has been observed (Prego et al. 2008a).

The biogeochemical cycle of copper in rias was recently surveyed (Prego and Cobelo-García 2003), and the pollution effects were investigated (Fernandez et al. 2008, Duran and Beiras 2010). The metal footprint, especially that of copper, in the harbour and shipyard shore-sediments of Vigo Ria was highlighted (Prego et al. 2008b). Natural inputs of copper into the Galician rias are usually low (Prego and Cobelo-García 2003). The anthropogenic contributions of dissolved and particulate copper due to sewage from water-treatment plants $\left(136 \mathrm{molCu} \mathrm{day}^{-1}\right)$ were found to be one order of magnitude higher than the fluvial supply $(15 \mathrm{molCu}$ day $^{-1}$ ) in early winter in the Ria of Vigo (Santos-Echeandía, et al. 2008). This total flux of copper is similar to the findings of Cobelo-Garcia and Prego (2004) for a small, but industrialized ria in Ferrol where water treatment does not exist. Therefore, copper spillage from diffuse sources must make a significant contribution to the sedimentary zone, which needs to be identified, around shipbuilding and repairing areas, harbours and the maritime traffic routes.

The purpose of this study was to assess the copper concentrations in sediments of the Galician rias and their harbour areas. There were three objectives: (a) to determine the copper distribution in the surface sediments of the Galician rias and their natural backgrounds; (b) to define the copper contamination levels in the harbour and shipyard areas of the rias; and (c) to suggest a simple criterion for identifying copper contamination on the Galician coast.

\section{MATERIALS AND METHODS}

\section{Survey area}

The Galician rias (Fig. 1) were defined by Evans and Prego (2003) as incised valleys where the estuarine zone can move according to climatic changes. The rias receive the main fluvial flow in the innermost area and, hydrographically, they show a mesotidal and semidiurnal pattern with a ria-ocean water exchange dominated by a positive residual circulation (Prego et al. 2001, Varela et al. 2005), except the Ferrol and Coruña Rias, in which the outflow is driven by tides (GómezGesteira et al. 2002, deCastro et al. 2004).

Torre-Enciso (1958) has classified the Galician Rias depending on their geological features into northern, middle and western rias (Fig. 1). The southernmost rias

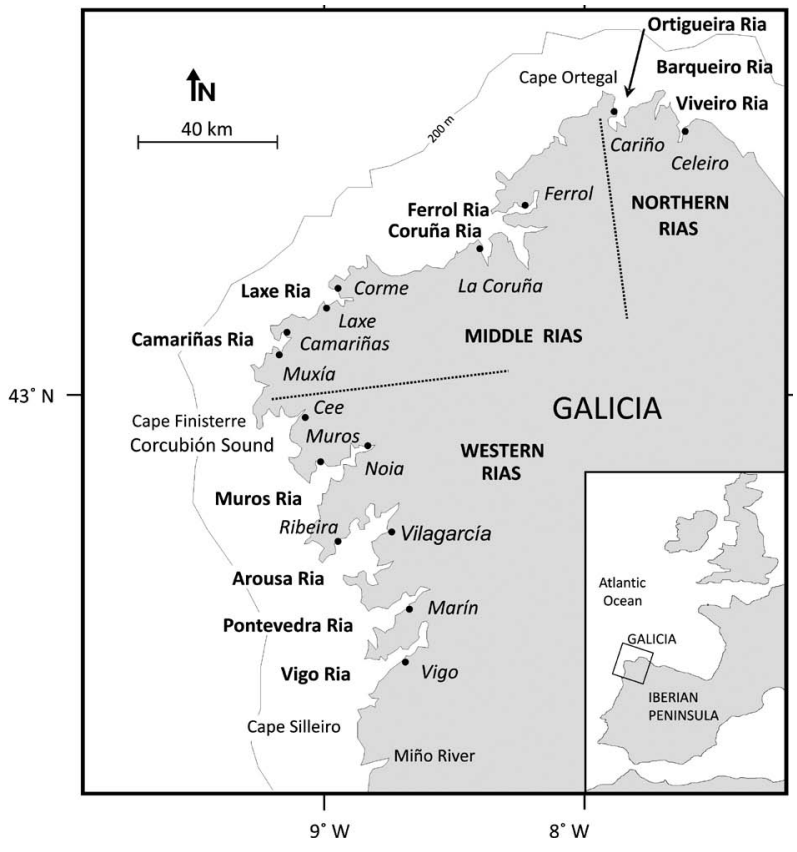

FIG. 1. - Map of Galicia with the location of harbours and rias under study.

of the Finisterre Cape constitute the western rias, namely, the rias of Vigo, Pontevedra, Arousa and Muros, which are the widest rias of Galicia, with surface areas of 120$230 \mathrm{~km}^{2}$ and mouth depths around $50 \mathrm{~m}$. Northern rias are located eastward of Cape Ortegal, while the middle rias are located between the two above-mentioned capes. Watersheds of the rias are composed of granites, schists and gneisses, and fluvial erosion plays the main role in ria sediments compared with lithological and tectonic influences (Torre-Enciso 1958).

Population, harbour activity and industries on the shores of the rias vary depending on each ria. The study of copper in sediments was focussed on the northern, middle and western Galician rias, where the main ( $\mathrm{La}$ Coruña, Ferrol and Vigo) and secondary harbours of the Galician coast are located (Fig. 1). The maritime traffic in these three aforementioned harbours is $27,000,000$ tons per year. In addition, 38\% of Spanish shipyards are located in Galicia and receive $40 \%$ of the money for the sale of ships. The Ferrol and Vigo Rias have the main shipyards (Prego et al. 2008a).

\section{Sampling and analysis}

A total of 389 surface sediment samples along the Galician coast were collected in the northern, middle and southern rias and their harbours (Figs 2, 3 and 4 , respectively). Sampling zones in the northern rias were: Viveiro (24 samples), O Barqueiro (29), Ortigueira (36) all sampled in July 2008; in the middle rias: Ferrol (33), La Coruña (11) both in September 1998, Laxe (19, in July 2000) and Camariñas (33, in September 2003); and in the southern rias: Corcubión (15, in May 2005), Muros (17), Arousa (66) both in September 1999, Pontevedra (37, in October 1998) and Vigo 
A)

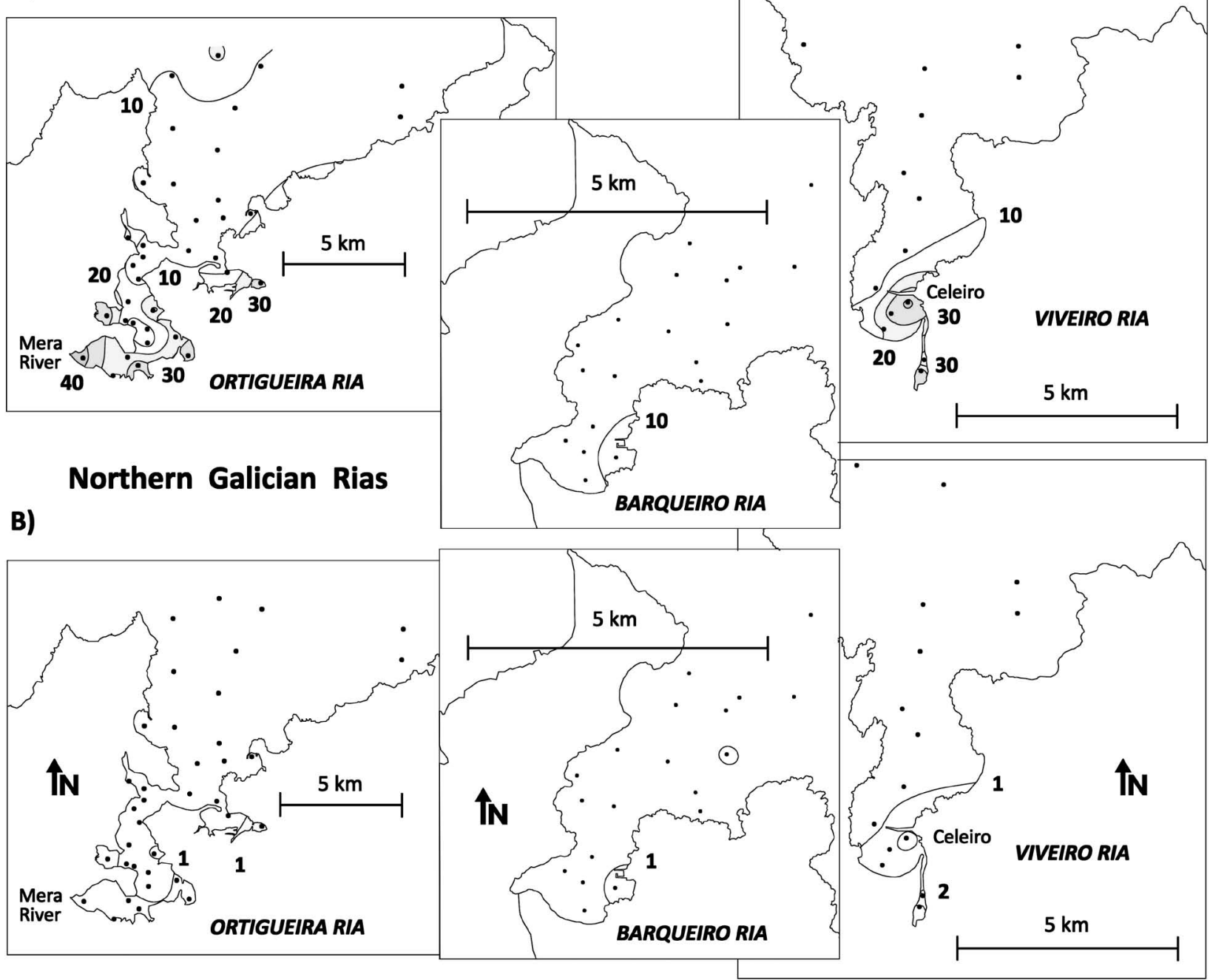

FIG. 2. - Isoline maps showing the fine fraction surface sediments of the northern Galician rias and their harbours: (a) the copper concentrations in $\mathrm{mg} \mathrm{kg}^{-1}$, and (b) the copper-iron relationship (NEF). Copper enrichment areas are highlighted with a blank background for negligiblemoderate contamination $(\mathrm{NEF}<3)$, light grey for severe contamination $(3<\mathrm{NEF}<6)$, grey for very severe $(6<\mathrm{NEF}<9)$ and dark grey for heavy contamination $(9<\mathrm{NEF})$.

(49, in October 1999). Samples were collected over ten years. The sedimentation rates in the middle-outer ria ranged from $0.5 \mathrm{~mm}$ to $3.9 \mathrm{~mm}$ per year (Desprat et al. 2003, Pena et al. 2010), i.e. a period of 3 to 20 years; moreover, the metal contamination pattern should not change in ria surface sediments (Prego et al. 2008b).

Sediments were retrieved using two Van Veen grabs $(30 \mathrm{~L}$ and $3.5 \mathrm{~L}$ capacity employed from the R/V and boats respectively) on board R/V Mytilus (IIMCSIC) or its auxiliary boat Zoea. In the northern rias and Corcubión Sound samples were collected on board $\mathrm{R} / \mathrm{V}$ Lura (IEO) and small boats in shallow waters. The sediment surface layer $(1 \mathrm{~cm})$ was extracted with a polyethylene spatula, stored in 200 -mL plastic flasks and placed into refrigerator at $4^{\circ} \mathrm{C}$. Later in the laboratory, sediment samples were oven-dried at $50^{\circ} \mathrm{C}$ and sieved through a $63 \mu \mathrm{m}$ sieve (Retsch AS-200). Sieved sediments were stored in plastic tubes until analysis. The plastic laboratory ware that was employed for sampling, storage and sample treatment was previously acid washed and rinsed thoroughly with Milli-Q water.

In order to quantify the background metal concentrations, five cores were retrieved using a Rossfelder P-3 vibrocorer and gravity-corer from R/V Mytilus. They were collected in the rias of Ferrol $(175 \mathrm{~cm}$ length and coordinates: $43^{\circ} 28.11^{\prime} \mathrm{N} \quad 8^{\circ} 14.86^{\prime} \mathrm{W}$ ), Muros ( $350 \mathrm{~cm}$ and $\left.42^{\circ} 45.50^{\prime} \mathrm{N} 8^{\circ} 59.90^{\prime} \mathrm{W}\right)$, Arousa (260 $\mathrm{cm}$ and $42^{\circ} 33.72^{\prime} \mathrm{N} 8^{\circ} 54.16^{\prime} \mathrm{W}$ ), and Vigo (135 $\mathrm{cm}$ and $42^{\circ} 13.37^{\prime} \mathrm{N} 8^{\circ} 49.37^{\prime} \mathrm{W}$ ), and the Corcubión Sound ( $100 \mathrm{~cm}$ and $\left.42^{\circ} 55.06^{\prime} \mathrm{N} 9^{\circ} 10.26^{\prime} \mathrm{W}\right)$. The cores were collected in PVC tubes and preserved at $4^{\circ} \mathrm{C}$ in a refrigerated chamber. The upper layer to a depth of 50 $\mathrm{cm}$ was removed in order to work with pre-industrial sediments only. Underneath this depth, cores were 
sectioned and slices of $1 \mathrm{~cm}$-thickness were extracted every $10 \mathrm{~cm}$ and processed in a similar way to the surface samples.

Around $0.1 \mathrm{~g}$ of each sediment sample was digested in Teflon bombs using a microwave oven (Milestone, MLS-1200 Mega), following the EPA guideline for siliceous type matrices (EPA 1996). The copper concentration was analysed by means of electrothermal atomic absorption spectrometry (ETAAS) using a Varian 220 apparatus equipped with the Zeeman background correction. Iron was determined as the normalizing element of the copper concentrations by means of flame atomic absorption spectrometry (FAAS) using a Varian 220-FS apparatus. Samples were handled and analysed in a clean laboratory (ISO 6). The accuracy of the analytical procedures employed for the analysis of both metals in the sediment samples was checked using the PACS-2 (NRC, Canada) certified reference material, and showed good agreement $\left(311 \pm 18 \mathrm{mgCu} \mathrm{kg}^{-1}\right.$ and $42.5 \pm 2.3$

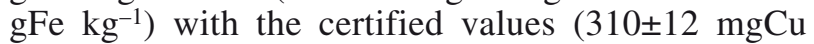
$\mathrm{kg}^{-1}$ and $40.9 \pm 0.6 \mathrm{gFe} \mathrm{kg}^{-1}$ ).

\section{RESULTS}

\section{Concentration and distribution of copper in ria sediments}

The distribution of copper in the surface sediment of the eleven studied rias is shown in Figs. 2a, 3a and 4a. The concentration of this metal ranged from 3 to $478 \mathrm{mg} \mathrm{kg}^{-1}$ with the highest levels in the Vigo Ria and the lowest in the northern rias together with the small rias of Camariñas and Laxe, with values up to $100 \mathrm{mg} \mathrm{kg}^{-1}$. In general, the copper values showed a decreasing trend from the contamination source towards the ocean. In the middle-outer ria areas the copper concentrations were usually lower than 30 $\mathrm{mg} \mathrm{kg}-1$. However, there was a local maximum in the harbour and/or shipyard areas, e.g. in the Bay of Bouzas and Teis of the Vigo Ria, in the Marin zone of Pontevedra Ria, in the harbour zone of Coruña Ria, and Ferrol-Caranza zones as well as in the shipyard areas in the southern-middle littoral of the Ferrol Ria. Furthermore, the copper concentration was also high in sediments of the fishing ports of Celeiro, Muxía, Camariñas, Laxe and Corme, the area for repairing small fishing boats at the head of Laxe Ria, and the Cee port next to the metallic carbide factory $(55 \mathrm{mg}$ $\mathrm{kg}^{-1}$; a figure of copper concentrations in the Sound of Corcubión was not included because its sampling was only a straight section). However, high values of copper were detected in surface sediments that are not directly related to harbour activities, e.g. those located at the semi-enclosed inlets of 'Grove' and Rianxo in the Arousa Ria, the Punta Corbeira shipyard area and intertidal zone around Noia town, the innermost zone of Ferrol Ria where there is an iron and steel recovery industry, and the mouth of Mera River in the Ortigueira Ria.
A)

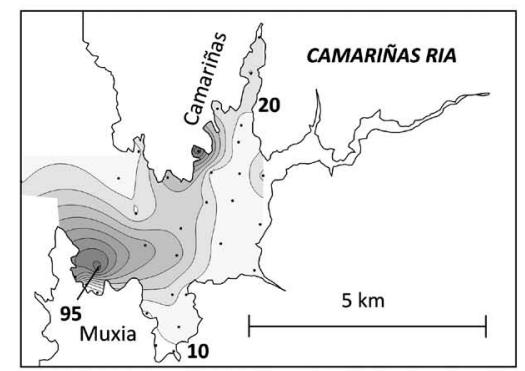

B) Middle Galician Rias

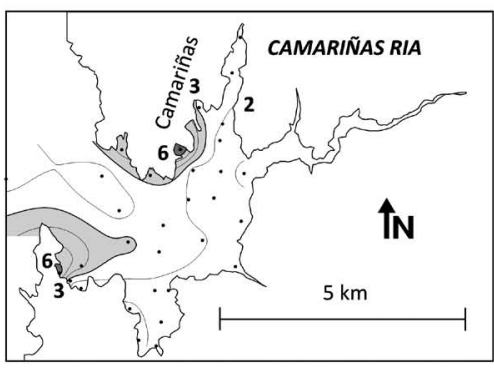

Isoline distances: $10 \mathrm{mg} \cdot \mathrm{kg}^{-1}$
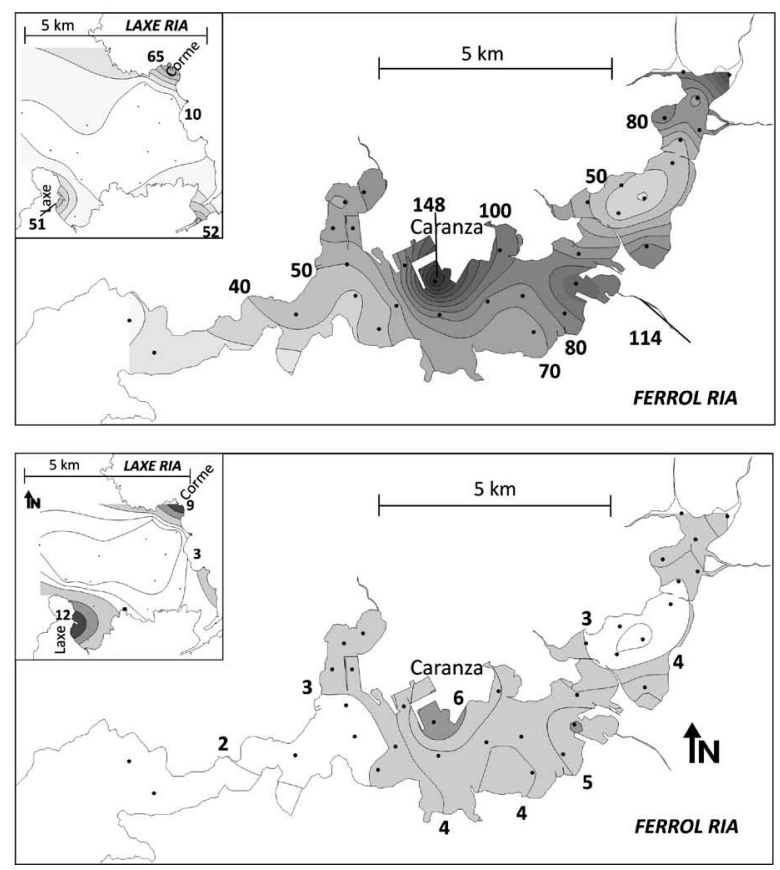
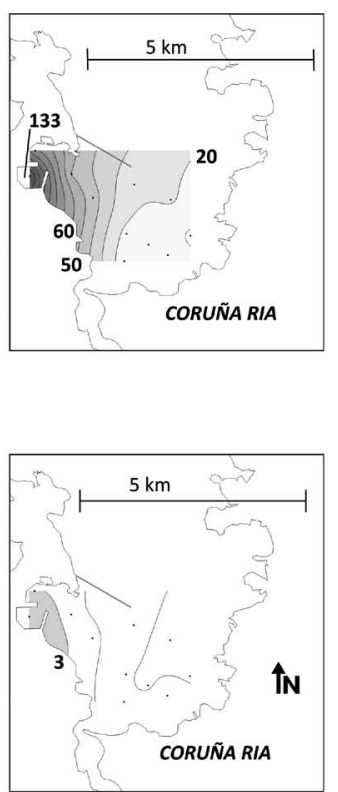

FIG. 3. - Isoline maps showing the fine fraction surface sediments of the middle Galician rias and their harbours: (a) the copper concentrations in $\mathrm{mg} \mathrm{kg}^{-1}$, and (b) the copper-iron relationship (NEF). Copper enrichment areas are highlighted with a blank background for negligiblemoderate contamination $(\mathrm{NEF}<3)$, light grey for severe contamination $(3<\mathrm{NEF}<6)$, grey for very severe $(6<\mathrm{NEF}<9)$ and dark grey for heavy contamination $(9<\mathrm{NEF})$. 
A)

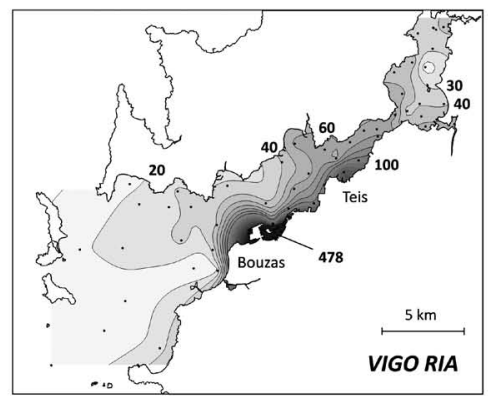

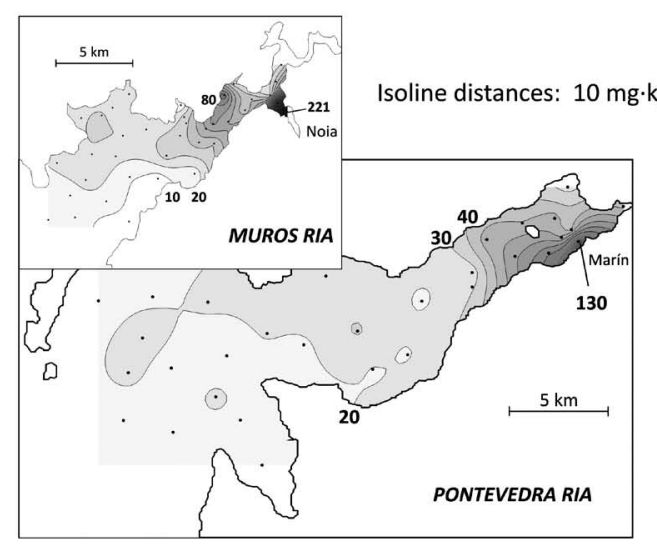

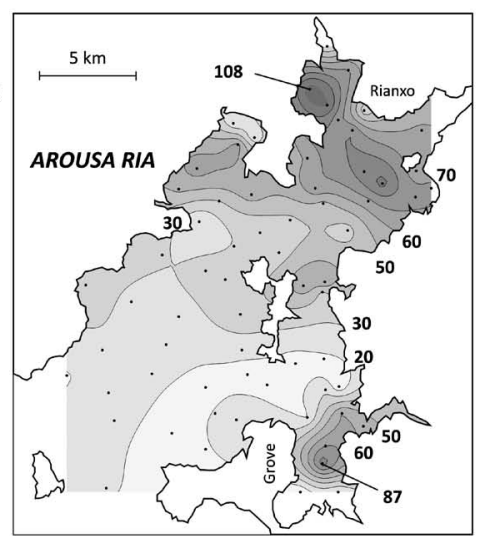

B) Western Galician Rias
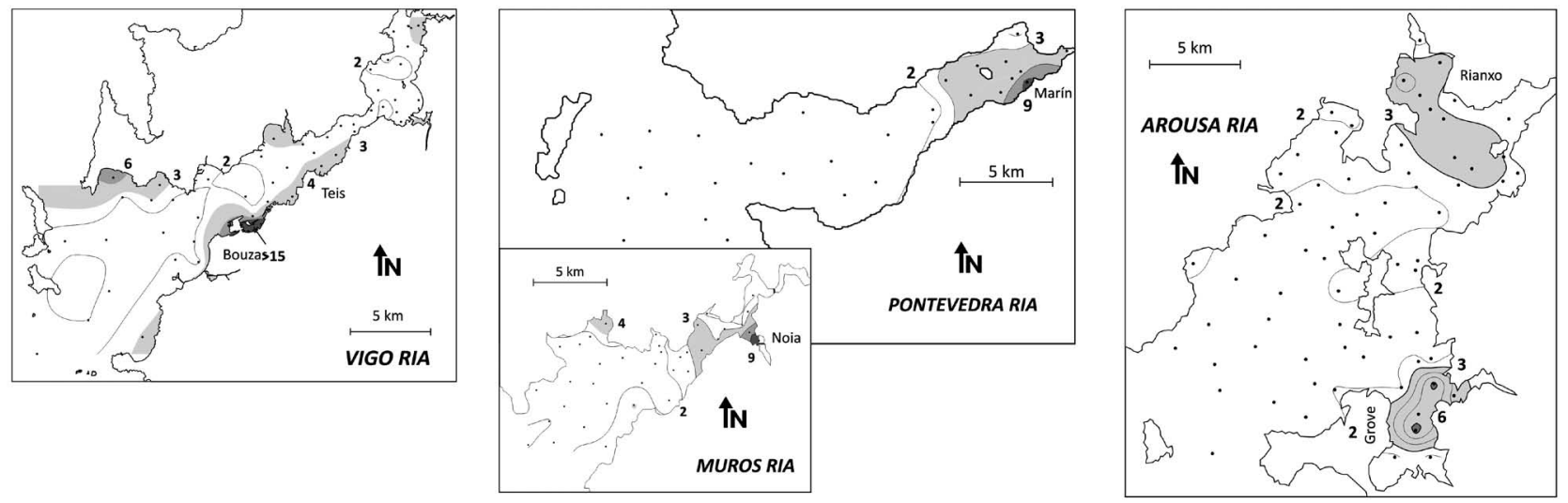

FIG. 4. - Isoline maps showing the fine fraction surface sediments of the western Galician rias and their harbours: (a) the copper concentrations in $\mathrm{mg} \mathrm{kg}^{-1}$, and (b) the copper-iron relationship (NEF). Copper enrichment areas are highlighted with a blank background for negligiblemoderate contamination $(\mathrm{NEF}<3)$, light grey for severe contamination $(3<\mathrm{NEF}<6)$, grey for very severe $(6<\mathrm{NEF}<9)$ and dark grey for heavy contamination $(9<\mathrm{NEF})$.

\section{Background copper ranges in ria sediments}

In order to distinguish the natural copper concentrations from anthropogenic additions in the sediments and to diagnose the contamination level, it is essential to establish a reference background concentration (BC), which is assumed to correspond to the pre-civilization metal concentrations (Prego and Cobelo-García 2003). Therefore, some conditions were followed to obtain a precise quantification of the $\mathrm{BC}$ for the sediments of the Galician rias:

(a) The natural presence of copper in the ria could be defined from its average level in the continental crust (Wedepohl 1991) or from its level in pristine sediments (Bryan and Langston 1992). This is not the most suitable approach because it does not take into account that the background concentration of copper in sediments varies according to the local geochemical composition. Therefore, the background concentration of copper in rias must be calculated from local data.

(b) Using a single copper concentration as the natural reference level for sediment normalization in rias is not appropriate. This was done in the rias (vg. Carbal- leira et al. 2000); however, copper richness depends on the geochemical sources and a metal-copper normalization equation based on local samples is desirable.

(c) The normalization equation needs to be established with respect to a conservative element of natural origin unaffected by anthropogenic contributions. The selection of the normalizer element cannot be solved by guesswork, but rather on the basis of geochemical characteristics of the river basins flowing to the rias. In this way, Fe can be used as a normalizer metal of $\mathrm{Cu}$ because it is an abundant element in the Galician granitic soils (Guitian 1992), its natural concentration in sediments is high (Prego and Cobelo-García 2003), it does not vary due to anthropogenic contributions and it is easy and fast to analyse by Flame AAS. Therefore, iron has already been used as a normalizing element in coastal systems and rias (Macias-Zamora et al. 1999, Cobelo-García and Prego 2003a, Chon Lin et al. 1998).

(d) Sediment from rias shows a wide range of grain size distributions in the extensive geographical area considered. The grain size distribution varies from siliciclastic sands associated with the river mouths, to siliciclastic mud with high organic matter content 
located under the mussel rafts and biogenic sands with gravel and low organic matter at the ria mouths (Vilas et al. 2005). Since particles smaller than $63 \mu \mathrm{m}$ have a very strong adsorptive potential for trace metals, contaminants are predominantly distributed and preconcentrated in this fraction (Hanson et al. 1993). For these reasons, it is best to carry out a second type of normalization with respect to sediment texture, and the fine fraction $(<63 \mu \mathrm{m})$ was selected to compare ria sediments in relation to adsorption and transport capacities related to metallic traces (Förstner 1987).

(e) The metal concentrations in surface sediments of the Galician rias were considered by means of regression techniques to determine the background concentrations (Carballeira et al. 2000). However, the BC determined from sediment cores is a more appropriate tool than selecting potential clean-contaminated sites in the rias. This has already been applied in the Ferrol Ria (Cobelo-García and Prego 2003a), where the sediment cores were accurately dated and iron was the element chosen for normalization as the pre-industrial deep sediment reference. Similarly, it could be applied to other rias, and the upper layer $(\sim 50 \mathrm{~cm})$ of cores will not be considered in the equation of copper normalization with iron.

Taking into account the above conditions, a linear relationship between copper and iron (Fig. 5) was obtained in sediment samples of five cores sampled along the Galician coast in the rias of Ferrol, Muros, Arousa and Vigo and Corcubión Sound. Consequently, the copper concentration $\left(\mathrm{mg} \mathrm{kg}^{-1}\right)$ in the sediment can be defined as a function of its iron content $\left(\mathrm{g} \mathrm{kg}^{-1}\right)$ expressed by the following equation:

$$
[\mathrm{Cu}]_{\mathrm{BC}}=0.52[\mathrm{Fe}]+1.0 \quad(\mathrm{r}=0.91 ; \mathrm{n}=73)
$$

\section{Copper enrichment and contamination of ria sediment}

The evaluation of the copper contamination levels in the rias and their harbour areas is based in the normalized enrichment factor (NEF), which was defined as the number of times that the reference concentration of natural conditions is exceeded (Tanner et al. 2000). Therefore, the NEF of copper is calculated by the following mathematical expression:

$$
\mathrm{NEF}_{\mathrm{Cu}}=[\mathrm{Cu}] /[\mathrm{Cu}]_{\mathrm{BC}}
$$

where $[\mathrm{Cu}]_{\mathrm{BC}}$ is the value of the background concentration of copper, provided by the copper-iron normalization equation (1).

Thus, the copper contamination state of the sediment can be defined in basis of NEF value (Prego et al. 2008b adapted from Hakanson 1980) as follows: negligible $<1 \leq$ possible $<2 \leq$ moderate $<3 \leq$ severe $<6 \leq$ very severe $<9 \leq$ heavy

Applying the above-mentioned criterion, the sediment of the rias can be considered as not or moderately

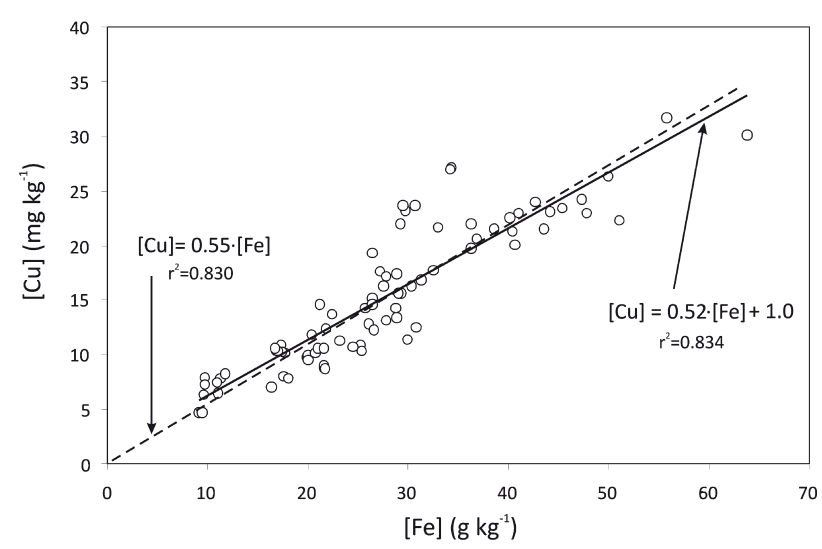

FIG. 5. - Regression line of copper versus iron concentrations in sediments from cores retrieved in the rias $(n=73)$. Dashed line depicts the regression line forced to go through the coordinates' origin.

contaminated in relation to copper (Figs $2 b, 3 b$ and 4b). Nevertheless, Ferrol Ria was an exception as the NEF ranges indicated severe contamination throughout the ria, except in the areas located at its mouth. On the contrary, the northern rias are almost pristine. In the remaining Galician rias there were isolated areas where the contamination state was detected. These areas corresponded to the harbour and shipyard shores, which have severe-heavy copper contamination in sediments, and were the following:

- Vigo Ria: all its southern middle part, i.e. the harbour zone, which had severe contamination, and particularly the shipyard area of Bouzas, which had heavy contamination;

- Pontevedra Ria: the shipyard and harbour of Marin, which had very severe contamination;

- Corcubión Sound: its inner part close to the Metalic Carbides Factory, which had severe contamination;

- Camariñas Ria: the zones close to the fishing ports of Muxia and Camariñas, which had severe contamination;

- Laxe Ria: the zones close to the fishing ports of Corme and Laxe, which had very severe contamination

- Coruña Ria: its harbour, which had severe contamination.

Occasionally, several areas in the rias showed a rise in the copper levels, i.e., those located near towns with small harbours in semi-enclosed bays such as Rianxo and Grove (severely contaminated) in Arousa Ria, and the Noia Town coast (severely contaminated) in Muros Ria.

\section{DISCUSSION}

The granitic nature of the Galician soils determines the lithological characteristics of the sediment components carried out to the rias (Vilas et al. 2005). The copper concentration in the land soils near the shoreline and fluvial basins running into the rias is usually low, in general it does not exceed $25 \mathrm{mg} \mathrm{kg}^{-1}$ (Guitian 1992). The results obtained in ria sediments are in good 
TABLE 1. - Copper concentration ranges in fine surface sediment of the main Galician Ria harbours compared to some world harbours.

\begin{tabular}{|c|c|c|c|}
\hline Harbour (country or ria) & {$[\mathrm{Cu}]\left(\mathrm{mg} \mathrm{kg}^{-1}\right)$} & Goods traffic $\left(10^{6} \mathrm{t} \mathrm{yr}^{-1}\right)$ & Reference \\
\hline Bouzas-Teis (Ria of Vigo) & $100-478$ & 5.1 & This study \\
\hline Coruña (Ria of La Coruña) & $50-133$ & 12.8 & This study \\
\hline Ferrol (Ria of Ferrol) & $100-148$ & 12.9 & This study \\
\hline Marin (Ria of Pontevedra) & $40-130$ & 1.7 & This study \\
\hline Vilagarcía (Ria of Arousa) & $50-80$ & 1.1 & This study \\
\hline Barcelona (Spain) & $70-530$ & 51 & Guevara-Riba et al. 2004 \\
\hline Bergen (Norway) & $25-1090$ & 38 & Paetzel et al. 2003 \\
\hline Ceuta (Spain) & $5-865$ & 1.4 & Guerra-García and García-Gómez 2005 \\
\hline Cork (Ireland) & $8-54$ & 4.0 & Kilemade et al. 2004 \\
\hline Elizabeth (South Africa) & $9-82$ & 31 & Fatoki and Mathabatha 2001 \\
\hline Hamilton (Canada) & $8-135$ & 12.0 & Poulton et al. 1996 \\
\hline Kaohsiung (Taiwan) & $5-946$ & 9.5 & Chen et al. 2007 \\
\hline Kembla (Äustralia) & $150-485$ & 27 & He and Morrison 2001 \\
\hline Keratsin (Greece) & $195-518$ & - & Galanopoulou et al. 2009 \\
\hline Montevideo (Uruguay) & $58-135$ & 8.7 & Muñiz et al. 2004 \\
\hline Port Reitz (Kenya) & $50-229$ & - & Muhoi et al. 2003 \\
\hline Singapore (Singapore) & $138-248$ & 483 & Orlic and Tang 1999 \\
\hline Sydney (Australia) & $20-701$ & 28 & McCready et al. 2006 \\
\hline Tolo (Hong Kong) & $6-231$ & 295 & Owen and Shandu 2000 \\
\hline Ventspils (Latvia) & $3-29$ & 28 & Müller-Karulis et al. 2003 \\
\hline
\end{tabular}

agreement with this pristine limitation due to the allochthonous continental source of copper. This source is quasi-homogeneous along the entire Galician coastal zone and fluvial basins; for this reason a significant Fe$\mathrm{Cu}$ correlation was obtained using preindustrial sediments from different rias as a whole (Fig. 5). Therefore, equation (1) can be applied to all the ria sediments in order to define their contamination level. As a reference, a simple criterion is proposed according to the following relationship (concentration of copper and iron in $\mathrm{mg} \mathrm{kg}^{-1}$ and $\mathrm{g} \mathrm{kg}^{-1}$ respectively):

$$
[\mathrm{Cu}] /[\mathrm{Fe}]=0.55 \quad(\mathrm{r}=0.91 ; \mathrm{n}=73)
$$

Now, the simple equation (3) can be used to define the copper contamination state in the Galician rias by analysing only the copper and iron concentrations in a sediment sample. Moreover, because the average copper concentrations in world soils commonly range from 20 to $30 \mathrm{mg} \mathrm{kg}^{-1}$ (Scheinberg 1991) the advanced ratio value could be applied in other coastal systems.

The anthropogenic influence is shown in the contaminated areas highlighted by the enrichment factor (Fig. 2b, 3b and 4b). According to the NEF distribution maps the non-natural source of sedimentary copper in the rias may be associated with harbours and shipyard littorals. This metal trend distribution was observed in previous studies in the Ferrol (Cobelo-García and Prego 2003a) and Pontevedra Rias (Cobelo-García and Prego 2003b). Although there are other possible sources of copper, such as the sewage and fluvial load (Cobelo-García and Prego 2003; Santos-Echeandía et al. 2008), these are not as important as the diffuse sources from shipping activities: antifouling release (Valkirs et al. 2003; Schiff et al. 2004) and shipyard loading (Turner 2010).

The focus of this copper contamination is mainly localized in the industrial bays of the rias. In these zones, the copper concentration reaches the sediment limits of marine quality (Klapow and Lewis 1979). The limit values are $34 \mathrm{mg} \mathrm{kg}^{-1}$, considered as the ERL (effects range-low; Byrkit 1975), and $270 \mathrm{mg} \mathrm{kg}^{-1}$ as the ERM (effects range-median), at which adverse biological effects usually occur (Long et al. 1995). The ria ecotoxicological status defined using the sea-urchin embryo test with sediment elutriates (Duran and Beiras 2010) has identified the Vigo and Marin harbours as polluted areas. In Galicia, copper contamination of sediments ranges from the coastal industrial areas and ports of Ferrol and Vigo, the most environmentally changed rias, to the pristine northern Galician rias, which are the most commercially isolated. Therefore, the Galician case exemplifies the type of copper contamination that is also observed in the world's harbours (Table 1), and which is especially significant in the Bergen (Paetzel et al. 2003), Sydney (McCready et al. 2006) and Kaohsiung (Chen et al. 2007) harbours.

\section{ACKNOWLEDGEMENTS}

The authors thank the crew of the R/V Mytilus and R/V Lura and our colleagues in the projects for their kind assistance during field work; Prof. R. Vidal-Romaní (Univ. of Coruña) and Prof. G. Francés (Univ. of Vigo) for the supply of some cores and W. Redondo (IIM-CSIC) and C. Almecija (IIM-CSIC) for core sampling. We are grateful to A. Rodríguez (IIM-CSIC) for her technical assistance; Dr. A. Tovar (IMEDEA-CSIC) and two anonymous reviewers for their comments, which helped us to improve our manuscript. This article is a contribution to the Spanish LOICZ program and it was partially supported by the projects with acronyms METRIA (ref. REN2003-04106-C03) and INTERESANTE (ref. CTM2007-62546-C03/MAR), financed by the Spanish CICYT. 


\section{REFERENCES}

Bryan G.W., Langston W.J. 1992. Bioavailability, accumulation and effects of heavy metals in sediments with special reference to United Kingdom estuaries: a review. Environ. Pollut. 76: 89-131.

Byrkit D. R. 1975. Elements of statistics, 2nd ed. D. Van Nostrand, New York, $431 \mathrm{pp}$.

Carballeira A., Carral E., Puente X., Villares R. 2000. Regionalscale monitoring of coastal contamination. Nutrients and heavy metals in estuarine sediments and organisms on the coast of Galicia (northwest Spain). Int. J. Environ. Pollut. 13: 534-572.

Chen C.-W., Kao C.-M., Chen C.-F., Dong C.-D. 2007. Distribution and accumulation of heavy metals in the sediments of Kaohsiung Harbor, Taiwan. Chemosphere 66: 1431-1440.

Chon-Lin L., Meng-Der F., Ming-Tsuen H. 1998. Characterization and distribution of metals in surficial sediments in Southwestern Taiwan. Mar. Pollut. Bull. 36: 464-471.

Cobelo-García A., Prego R. 2003a. Heavy metal sedimentary record in a Galician Ria (NW Spain): background values and recent contamination. Mar. Pollut. Bull. 46: 1253-1262.

Cobelo-García A., Prego R. 2003b. Land inputs, behaviour and contamination levels of copper in a ria estuary (NW Spain). Mar. Environ. Res. 56: 403-422.

Cobelo-García A., Prego R. 2004. Influence of point sources on trace metal contamination and distribution in a semi-enclosed industrial embayment: The Ferrol Ria (NW Spain). Est. Coast. Shelf. Sci. 60: 695-703.

deCastro M., Gómez-Gesteira M., Prego R., Álvarez I. 2004. RiaOcean exchange driven by tides in the Ria Ferrol (NW Spain). Est. Coast. Shelf Sci. 61: 15-24.

Desprat S., Sanchez-Goñi M.F., Loutre M.-F. 2003. Revealing climatic variability of the last three millennia in northwestern Iberia using pollen influx data. Earth Planet. Sci. Lett. 213: 63-78.

Durán I., Beiras R. 2010. Assessment criteria for using the seaurchin embryo test with sediment elutriates as a tool to classify the ecotoxicological status of marine water bodies. Environ. Toxicol. Chem. 29: 1192-1198.

EPA. 1996. Method 3052. Microwave assisted acid digestion of siliceous and organically based matrices.

Evans G., Prego R. 2003. Rias, estuaries and incised valleys: is a ria an estuary? Mar. Geol. 196: 171-175.

Fatoki O.S. Mathabatha S. 2001. An assessment of heavy metal pollution in the East London and Port Elizabeth harbours, Water SA 27: 233-240.

Feng H., Cochram K., Lwiza H., Brownawell B.J., Hirschberg D.J. 1998. Distribution of heavy metal and PCB contaminants in the sediments of an urban estuary: the Hudson River. Mar. Environ. Res. 45: 69-88.

Fernández N., Lorenzo I., Beiras R. 2008. Integrative assessment of coastal pollution in a Ría coastal system (Galicia, NW Spain): Correspondence between sediment chemistry and toxicity. Chemosphere 72: 826-835.

Fichet D., Boucher G., Radenac G., Miramand P. 1999. Concentration and mobilisation of $\mathrm{Cd}, \mathrm{Cu}, \mathrm{Pb}$ and $\mathrm{Zn}$ by meiofauna populations living in harbour sediment: their role in the heavy metal flux from sediment to food web. Sci. Total Environ. 243/244: 263-272.

Förstner U. 1987. Sediment-associated contaminants. An overview of basis for developing remedial options. Hydrobiologia 149 : 221-246.

Galanopoulou S., Vgenopoulos A., Conispoliatis N. 2009 Anthropogenic heavy metal pollution in the surficial sediments of the Keratsini Harbor, Saronikos Gulf, Greece. Water Air Soil Pollut. 202: 121-130.

Gómez-Gesteira M., deCastro M., Prego R., Martíns F. 2002. Influence of the Barrie de la Maza Dock on the Circulation Pattern of the Ría of A Coruña (NW - Spain). Sci. Mar. 66: 337-346.

Guerra-García J.M., García-Gómez J. C. 2005. Assessing pollution levels in sediments of a harbor with two opposing entrances. Environmental implications. J. Environ. Manage. 77: 1-11.

Guevara-Riba A., Sahuquillo A., Rubio R., Rauret G. 2004. Assessment of metal mobility in dredged harbour sediments from Barcelona, Spain. Sci. Total Environ. 321: 241-255.

Guitian F. 1992. Atlas geoquímico de Galicia. Xunta de Galicia, Santiago de Compostela.
Hakanson L. 1980. An ecological risk index for aquatic pollution control. A sedimentological approach. Water Res. 14: 975-1001.

Hanson P.J., Evans D.W., Colby D.R., Zdanowicz V.S. 1993. Assessment of elemental contamination in estuarine and coastal environments based on geochemical and statistical modeling of sediments. Mar. Environ. Res. 36: 237-266.

He, Z., Morrison R.J. 2001. Changes in the Marine Environment of Port Kembla Harbour, NSW, Australia, 1975-1995: A Review. Mar. Pollut. Bull. 42: 193-201.

Kennish M.J. 1992. Ecology of estuaries: Anthropogenic effects. CRC Press, Boca Raton.

Kilemade M., Hartl M.G.J., Sheehan D., Mothersill C., van Pelt F.N.A.M., O’Brien N.M., O'Halloran J. 2004. An assessment of the pollutant status of surficial sediment in Cork Harbour in the South East of Ireland with particular reference to polycyclic aromatic hydrocarbons. Mar. Pollut. Bull. 49: 1084-1096.

Klapow L.A., Lewis R.H. 1979. Analysis of toxicity data for California marine water quality standards. J. Water Pollut. Control Fed. 51: 2051-2070.

Long E.R., Macdonald D.D., Smith S.L., Calder F.D. 1995. Incidence of adverse biological effects within ranges of chemical concentrations in marine and estuarine sediments. Environ. Manage. 19 (1): 81-97.

Macías-Zamora J.V., Villaescusa-Celaya J.A., Muñoz-Barbosa A., Gold-Bouchot G. 1999. Trace metals in sediment cores from the Campeche shelf, Gulf of Mexico. Environ. Pollut. 104, (1): 69-77.

Mason, R.P., Kim E.H., Cornwell J. 2004. Metal accumulation in Baltimore Harbor: current and past inputs. App. Geochem. 19: 1801-1825.

McCready S., Birch G.F., Long E.R. 2006. Metallic and organic contaminants in sediments of Sydney Harbour, Australia and vicinity - A chemical dataset for evaluating sediment quality guidelines. Environ. Int. 32: 455-465.

Müller-Karulis B., Poikane R., Seglins V. 2003. Heavy metals in the Vent spills harbour: normalization based on a multi-parameter dataset, Environ. Geol. 43: 445-456.

Muñiz P., Danulat E. Yannicelli B., García-Alonso A., Medina G., Bícego M.C. 2004. Assessment of contamination by heavy metals and petroleum hydrocarbons in sediments of Montevideo Harbour (Uruguay). Environ. Int. 29: 1019-1028.

Muohi A., Onyari J.M., Omondi J.G., Mavuti K.M. 2003. Heavy metals in sediments from Makupa and Port-Reitz Creek systems: Kenyan Coast. Environ. Int. 28: 639-647.

Orlic I., Tang S.M. 1999. Elemental depth profiles in marine sediments of Singapore coastal waters. Nucl. Instrum. Meth. B 150: 291-297.

Owen R.B., Sandhu N. 2000. Heavy metal accumulation and anthropogenic impacts on Tolo Harbour, Hong Kong, Mar. Pollut. Bull. 40: 174-180.

Paetzel M., Nes G., Leifsen L.O., Schrader H. 2003. Sediment pollution in the Vägen, Bergen harbour, Norway. Environ. Geol. 43: 476-483.

Pena L.D., Francés G., Diz P., Esparza M., Grimalt J.O., Nombela M.A. 2010. Climate fluctuations during the Holocene in NW Iberia: high and low latitudes linkages. Cont. Shelf Res. 30: 1487-1496.

Poulton D.J., Morris W.A., Coakley J.P. 1996. Zonation of contaminated bottom sediments in Hamilton Harbour as defined by statistical classification techniques, Water Qual. Res. J. Canada 31: 505-528.

Prego R., Cobelo-García A. 2003. 20 th Century overview of heavy metals in the Galician Rias (NW Iberian Peninsula). Environ. Pollut. 121: 425-452

Prego R., Dale A.W., deCastro M., Gómez-Gesteira M., Taboada J.J., Montero P., Ruiz-Villareal M., Pérez-Villar V. 2001. Hydrography of the Pontevedra Ria: Intra-Annual spatial and temporal variability in an Galician Coastal system (NW Spain). J. Geophys. Res. 106 (C9): 19845-19858.

Prego R., Ferro P., Trujillo C. 2008a. Lead and Zinc contamination of surface sediments in the main harbours of the Galician Rias. J. Iberian Geol. 34 (2): 243-252.

Prego R., Filgueiras A.V., Santos-Echeandía J. 2008b. Temporal and spatial changes of total and labile metal concentration in the surface sediments of the Vigo Ria (NW Iberian Peninsula): Influence of anthropogenic sources. Mar. Pollut. Bull. 56: $1022-1042$. 
Santos-Echeandía J., Laglera L.M., Prego R., Van den Berg C.M.G. 2008. Copper speciation in continental inputs to the Vigo Ria: Sewage discharges versus river fluxes. Mar. Pollut. Bull. 56: 308-317.

Scheinberg I.H. - 1991. Copper. In: E. Merian (ed.), Metals and their compounds in the environment. Wiley VCH Wienheim, pp. 803-851.

Schiff K., Diehl D., Valkirs A. 2004. Copper emissions from antifouling paint on recreational vessels. Mar. Pollut. Bull. 48 : 371-377.

Seligman P.F. Valkirs A.O., Caso J.S., Rivera-Duarte I., Haslbeck E. 2001. Copper release rates from antifouling marine coatings and their relationship to loading and toxicity in San Diego Bay, CA. In: M.A. Champ (ed.), Symposium on Pollution Prevention from Ships and Shipyards. Oceanology International 2001 Conference. Miami, FL, pp. 64-81.

Sobral P., Widdows J. 1997. Effects of copper exposure on the scope for growth of the clam Ruditapes decussatus from southern Portugal. Mar. Pollut. Bull. 34: 992-1000.

Tanner P.A., Leong L.S., Pan S.M. 2000. Contamination of heavy metals in marine sediment cores from Victoria Harbour, Hong Kong. Mar. Pollut. Bull. 40: 769-779.

Torre-Enciso E. 1958. Estado actual del conocimiento de las rías. In: Homenaxe a Otero Pedrayo. Galaxia, Vigo, pp. 237-250
Turner A. 2010. Marine pollution from antifouling paint particles. Mar. Pollut. Bull. 60: 159-171.

Valkirs A.O., Seligman P.F. Haslbeck E., Caso J.S. 2003. Measurement of copper release rates from antifouling paint under laboratory and in-situ conditions: implications for loading estimation to marine water bodies. Mar. Pollut. Bull. 46: 763-779.

Varela M., Prego R., Pazos Y., Moroño A. 2005. Influence of upwelling and river runoff interaction of phytoplankton assemblages in a Middle Galician Ria ans comparison with northern and southern rias (NW Iberian Peninsula). Est., Coast. Shelf Sci. 64: 721-737.

Vilas F., Bernabeu A.M., Mendez G. 2005. Sediment distribution pattern in the Rias Baixas (NW Spain): main facies and hydrodynamic dependence. J. Mar. Syst. 54: 261-276.

Wedepohl K.H. - 1991. The composition of the upper earth's crust and the natural cycles of select metals. In: E. Merian (ed.), Metals and their compounds in the environment. Willey VCH, Wienheim, pp. 3-17.

Wolanski E. 2006. The Environment en Asia Pacific Harbours. Springer, Amsterdam.

Received August 19, 2010. Accepted February 25, 2011.

Published online January 7, 2013. 